\title{
Impact of alien plants in Turkey assessed by the Generic Impact Scoring System
}

\author{
Ayşe Yazlık ${ }^{1,2}$, Jan Pergl', Petr Pyšek ${ }^{1,3}$ \\ I The Czech Academy of Sciences, Institute of Botany, Department of Invasion Ecology, CZ-252 43 Prühonice, \\ Czech Republic 2 Department of Plant Protection, Faculty of Agriculture and Nature Sciences, Düzce Univer- \\ sity, Düzce, Türkiye 3 Department of Ecology, Faculty of Science, Charles University, Viničná 7, CZ-128 44 \\ Prague, Czech Republic
}

Corresponding author: Ayşe Yazllk (ayseyazlik@gmail.com)

Academic editor: J. Catford | Received 12 January 2018 | Accepted 12 June 2018 | Published 27 June 2018

Citation: Yazlık A, Pergl J, Pyšek P (2018) Impact of alien plants in Turkey assessed by the Generic Impact Scoring System. NeoBiota 39: 31-51. https://doi.org/10.3897/neobiota.39.23598

\begin{abstract}
In this paper, we present the impact categorizations of 51 alien plant species in Turkey, which were determined using the Generic Impact Scoring System (GISS). The evidence on environmental and socioeconomic impacts of these alien species was searched in literature. Impacts were classified into 12 categories (six for environmental and six for socioeconomic) and, within each category, the impact was assessed on a six degree scale. Environmental impacts were recorded for $80 \%$ of the species and mostly concern ecosystem processes (changes in nutrient or water availability and disturbance regimes), while socioeconomic impacts, identified for $78 \%$ of the species assessed, are typically associated with agricultural production or human health. Summed scores of individual species across categories of environmental and socioeconomic impacts were not significantly correlated. By taking into account the actual distribution of the assessed species, we evaluated the regional distribution of (potential) impacts in Turkey. The Black Sea region harbours the highest number of species with impacts (34 species, i.e. $67 \%$ of the total assessed for the whole country), 28 species were recorded in the Marmara, 21 in the Mediterranean, 17 in the Aegean and 12 in each of the South East Anatolia, Central Anatolia and East Anatolia regions. The species that have negative impact on forestry are only found in three regions. Altogether 21 species are agricultural weeds, but we only found evidence of a minor socioeconomic impact for some of them. Determining the impacts based on specific criteria (i) provides basis for objective risk assessment of plant invasions in Turkey, (ii) can be taken as early warning to combat these plants and (iii) contributes to the growing body of evidence of the impacts of alien plant species.
\end{abstract}

Copyright AyșeYazlık et al. This is an open access article distributed under the terms of the Creative Commons Attribution License (CC BY 4.0), which permits unrestricted use, distribution, and reproduction in any medium, provided the original author and source are credited. 


\section{Keywords}

alien species, environmental impact, GISS socioeconomic impact, regional distribution, management, sector analysis

\section{Introduction}

In the last decade, evidence has accumulated about serious negative impacts of alien species on the environment, economy and human well-being in all parts of the world (Vilà et al. 2010, 2011, Ricciardi et al. 2013, Kumschick et al. 2015b, Rumlerová et al. 2016, Nentwig et al. 2018). These impacts range from effects on individuals (e.g. competition, transfer of diseases, genetic and evolutionary changes) through populations, species and communities to those affecting whole ecosystems and their functioning (Parker et al. 1999, Ehrenfeld 2010, Pyšek et al. 2012, Simberloff et al. 2013). Many invasive species have been shown to have negative socioeconomic impacts (Perrings et al. 2010, Bacher et al. 2018). Overall, there is robust scientific evidence that biological invasions can not only decrease the diversity of native species, but can also negatively affect animal and human health in the invaded areas (Weber 2003, Richardson and Pyšek 2006, Lambdon et al. 2008, Pyšek and Richardson 2010, Hulme 2013, Schindler et al. 2015).

A strong commitment of the European Commission to provide solid and sustainable solutions regarding the management of invasive alien species in Europe is on record (Roy et al. 2013, EU 2014, Genovesi et al. 2015). According to recent European Union legislation, there will be a mandatory response by all member states to the threats that invasive species pose to biodiversity and ecosystem services. The new regulation includes, after the first update in 2017, a list of 49 invasive alien species, which may be a threat or of concern in EU member states. To be included on this list, a full risk assessment, including evaluation of impact of a candidate species, has to be completed by experts, reviewed by members of the Scientific Forum and accepted by the European Commission and member states (EU 2014).

The evaluation of the impacts of individual species varies amongst regions and stakeholders in different sectors, such as nature protection, forestry or hunting (Sladonja et al. 2015, Vítková et al. 2017). For management, identifying the most deleterious species is a priority (Pergl et al. 2016). Hence, a robust and objective approach to rank alien species impacts through standard procedures is required (Nentwig et al. 2010, Vaes-Petignat and Nentwig 2014, Kumschick et al. 2015a, 2017, Rumlerová et al. 2016). To achieve this goal, two comprehensive methods to assess socioeconomic and/or environmental impacts were proposed recently (Nentwig et al. 2010, Blackburn et al. 2014). The Environmental Impact Classification for Alien Taxa (EICAT; Blackburn et al. 2014, Hawkins et al. 2015), now adopted as an official instrument of IUCN (https://www.iucn.org/theme/species/our-work/invasive-species/eicat), enables the environmental impacts of all alien taxa to be classified. Socioeconomic impacts 
are covered by the recent framework SEICAT (Bacher et al. 2018), where the evaluation is based on the change in human well-being, rather than on eradication costs and monetary loss from, for example, reduced yield - approaches that were used previously. However, for risk assessments to be considered by EU as a basis for prioritization, it is required that all possible impacts of alien species be evaluated, including those on human health and economy (Roy et al. 2013). These aspects are covered by the second scheme, the Generic Impact Scoring System (GISS; Nentwig et al. 2010, 2016) which was introduced in a study on mammals alien to Europe (Nentwig et al. 2010) and then applied to other taxonomic groups (e.g. Kumschick and Nentwig 2010, Vaes-Petignat and Nentwig 2014, van der Veer and Nentwig 2014, Laverty et al. 2015, Novoa et al. 2016, Rumlerová et al. 2016). While assessment of each additional group required some specific modifications and additional features were being included in GISS, the system remained generic (see Nentwig et al. 2016 for summary and update). Out of the 12 impact categories in GISS, there are six categories for environmental impacts and six for socioeconomic impacts. The information generated through the development of such a system can provide decision-makers and other stakeholders with guidelines for prioritization of threats imposed by alien species and identify species to be targeted by management (Nentwig et al. 2010, Pergl et al. 2016, Rumlerová et al. 2016).

Our study focuses on Turkey, a country spanning three floristic (Mediterranean, Irano-Turanian and Euro-Siberian) and seven climatic zones, which results in a remarkably rich flora. Turkey harbours 9,342 species of seed plants, of which 31\% are endemic (Güner et al. 2012). This diversity is threatened by many factors related to human activities, amongst which alien species represent an important issue. Unfortunately, the information on alien flora in Turkey remained rather scattered until recently. Many alien plant species were reported especially from North-East of Anatolia, the East Black Sea region in particular and mostly recorded in forest or tea plantations (e.g. Terzioğlu and Ansin 1999, Coşkunçelebi et al. 2007, Karaer and Kutbay 2007, Brundu et al. 2011, Eminağaoğlu et al. 2012, Karaer and Terzioğlu 2013). Çinar et al. (2011) presented a detailed study of naturalized alien species from the coast of Turkey and Uludağ et al. (2017), in the recently published first study on the alien flora of the whole country, reported a total number of 340 alien taxa. Of these, $228(68 \%)$ are naturalized and 112 (32\%) are casual species. About two thirds were introduced deliberately, mostly as ornamentals, forestry species or crops, while 110 species were introduced unintentionally. Of the total pool of alien species in the country, 23\% occur in agricultural areas, amongst them $16 \%$ as naturalized and $7 \%$ as casual (Uludağ et al. 2017).

With this new source on the alien plant species diversity in Turkey (Uludağ et al. 2017), assessing their impacts appears the logical next step. The aims of the present study were thus to determine, by applying GISS, (i) which alien plant species have the greatest potential environmental and socioeconomic impacts, (ii) which impact types represent the greatest threat and (iii) which sectors (forestry and agriculture) and regions in Turkey are most affected. 


\section{Methods}

\section{Selection of species}

To select the species for our study, we considered plants alien to Turkey (following the definition of Pyšek et al. 2004, Blackburn et al. 2011), as reported in Uludağ et al. (2017). The selection process aimed at identifying plant species with potential environmental and socioeconomic impacts in Turkey, i.e. those that were suggested as problematic in the local literature (see e.g. Eminağaoğlu et al. 2012, Karaer and Terzioğlu 2013, Uruşak et al. 2013, Uremiş et al. 2014), including master and doctoral theses (Yazlık 2001, Yıldırım 2001, Kitiş 2002). Some of these alien species are already widely distributed in the country but some were introduced to Turkey as late as the last two decades, which allows determination of their potential impacts before they start to spread across large areas, possibly further increasing their abundance. The screening yielded 51 species meeting the above criteria that were included in the evaluation of impacts. All evaluated species are neophytes, 31 are considered naturalized and 20 are still in the casual stage (according to the criteria described in Richardson et al. 2000, Blackburn et al. 2011) (Table 1).

\section{Scoring of impacts}

We used the Generic Impact Scoring System (GISS; Nentwig et al. 2016) to quantify the negative impacts (environmental, socioeconomic) of the selected alien plant species. The GISS includes 12 categories, with their impact within each category scored in the range of zero to five, giving six possible scores. A score of "zero" means that an alien species has no impact (or an unknown impact) and "five" represents the maximum impact. The impact levels were assigned based on published literature, grey literature, including master and doctoral theses and local reports (Suppl. material 3).

The data on particular impacts were searched using (i) ISI Web of Knowledge, by including a species' scientific name combined with keywords indicating its alien/naturalized/invasive status and impact; (ii) databases of invasive species with their impacts recorded, namely DAISIE, NOBANIS (The European Network on Invasive Alien Species, www.nobanis.org ) and GISD (The Global Invasive Species Database, www. issg.org), also searching the references on which these impacts were based; and (iii) other bibliographic sources of information including regional and national case studies (mainly theses and reports from Turkey) and books mentioned in the primary literature. We considered evidence for the impact of individual species across their whole invaded range, not only in Turkey (see e.g. Rumlerová et al. 2016).

The environmental impacts consist of: impact on plants or vegetation (category 1.1), impact on animals (e.g. through altered food availability) (1.2), impact on other species through competition (1.3), impact through transmission of diseases or para- 
Table I. Environmental (Env.), socioeconomic (Soc.) and total (logarithmic sum; see text for explanation) impacts of alien species in Turkey. Each taxon is listed with its family, life form, life history, invasion status in Turkey (Cas = casual, Nat = naturalized; Pyšek et al. 2004, Blackburn et al. 2011), native range and distribution extent in Turkey. Status as an agricultural weed, based on literature, is indicated (see text for details).

\begin{tabular}{|c|c|c|c|c|c|c|c|c|c|c|c|}
\hline No & Species & Family & Env. & Soc. & $\begin{array}{l}\text { Total } \\
\text { score }\end{array}$ & $\begin{array}{l}\text { Agr. } \\
\text { weed }\end{array}$ & $\begin{array}{l}\text { Life } \\
\text { form }\end{array}$ & $\begin{array}{c}\text { Life } \\
\text { history }\end{array}$ & Status & Native range & $\begin{array}{l}\text { Number of } \\
\text { grid cells } \\
\text { (See Suppl. } \\
\text { material 1) }\end{array}$ \\
\hline 1 & $\begin{array}{l}\text { Acalypha } \\
\text { australis }\end{array}$ & \begin{tabular}{|c|}
$\begin{array}{c}\text { Euphorbi- } \\
\text { aceae }\end{array}$ \\
\end{tabular} & 0 & 2.00 & 2.00 & Yes & Herb & Annual & Nat & Asia & 1 \\
\hline 2 & Acer negundo & Sapindaceae & 3.00 & 2.05 & 3.05 & No & Tree & Perennial & Nat & N America & 2 \\
\hline 3 & $\begin{array}{l}\text { Aethionema } \\
\text { carneum }\end{array}$ & Brassicaceae & 0 & 1.04 & 1.04 & Yes & Herb & Annual & Nat & SW Asia & 3 \\
\hline 4 & Agave americana & $\begin{array}{c}\text { Aspara- } \\
\text { gaceae }\end{array}$ & 3.04 & 2.00 & 3.08 & No & $\begin{array}{l}\text { Herb/ } \\
\text { Shrub }\end{array}$ & \begin{tabular}{|l|} 
Perennial \\
succulent
\end{tabular} & Cas & N America & 4 \\
\hline 5 & $\begin{array}{l}\text { Ailanthus } \\
\text { altissima }\end{array}$ & $\begin{array}{c}\text { Simarou- } \\
\text { baceae }\end{array}$ & 3.48 & 3.00 & 3.60 & No & Tree & Perennial & Nat & Asia & 2 \\
\hline 6 & $\begin{array}{l}\text { Alhagi } \\
\text { pseudalhagi }\end{array}$ & Fabaceae & 2.00 & 2.00 & 2.30 & Yes & Shrub & Perennial & Nat & $\begin{array}{l}\text { West Asia, } \\
\text { Europe }\end{array}$ & 11 \\
\hline 7 & $\begin{array}{l}\text { Alyssum } \\
\text { dasycarpum }\end{array}$ & Brassicaceae & 0 & 2.00 & 2.00 & Yes & Herb & Annual & Nat & Asia, Europe & 13 \\
\hline 8 & $\begin{array}{l}\text { Alyssum } \\
\text { sibiricum }\end{array}$ & Brassicaceae & 0 & 2.00 & 2.00 & Yes & Herb & Perennial & Nat & Asia, Europe & 14 \\
\hline 9 & Alyssum strictum & Brassicaceae & 0 & 2.00 & 2.00 & Yes & Herb & Annual & Nat & Asia, Europe & 9 \\
\hline 10 & $\begin{array}{l}\text { Alyssum } \\
\text { strigosum subsp. } \\
\text { strigosum }\end{array}$ & Brassicaceae & 0 & 2.00 & 2.00 & Yes & Herb & Annual & Nat & Asia, Europe & 14 \\
\hline 11 & $\begin{array}{l}\text { Amaranthus } \\
\text { caudatus }\end{array}$ & $\begin{array}{l}\text { Amaran- } \\
\text { thaceae }\end{array}$ & 2.3 & 1.04 & 2.32 & No & Herb & Annual & Nat & S America & 1 \\
\hline 12 & $\begin{array}{l}\text { Amaranthus } \\
\text { hybridus }\end{array}$ & $\begin{array}{c}\text { Amaran- } \\
\text { thaceae }\end{array}$ & 3.04 & 2.05 & 3.08 & Yes & Herb & Annual & Nat & $\begin{array}{l}\text { C America, } \\
\text { N America }\end{array}$ & 3 \\
\hline 13 & $\begin{array}{l}\text { Amaranthus } \\
\text { retroflexus }\end{array}$ & $\begin{array}{c}\text { Amaran- } \\
\text { thaceae }\end{array}$ & 3.32 & 3.00 & 3.49 & Yes & Herb & Annual & Nat & $\begin{array}{l}\text { C America, } \\
\text { N America }\end{array}$ & 5 \\
\hline 14 & $\begin{array}{l}\text { Amaranthus } \\
\text { spinosus }\end{array}$ & $\begin{array}{c}\text { Amaran- } \\
\text { thaceae }\end{array}$ & 2.00 & 2.48 & 2.60 & Yes & Herb & Annual & Nat & Trop. America & 1 \\
\hline 15 & $\begin{array}{l}\text { Ambrosia } \\
\text { artemisiifolia }\end{array}$ & Asteraceae & 4.00 & 3.08 & 4.05 & Yes & Herb & Annual & Nat & N America & 2 \\
\hline 16 & $\begin{array}{l}\text { Amorpha } \\
\text { fruticosa }\end{array}$ & Fabaceae & 4.00 & 0 & 4.00 & No & Shrub & Perennial & Cas & N America & 1 \\
\hline 17 & Artemisia annua & Asteraceae & 3.00 & 4.00 & 4.50 & No & Herb & Annual & Nat & W Asia & 7 \\
\hline 18 & $\begin{array}{l}\text { Artemisia } \\
\text { verlotiorum }\end{array}$ & Asteraceae & 3.04 & 3.00 & 3.08 & No & Herb & Perennial & Nat & Asia & 1 \\
\hline 19 & Bidens bipinnata & Asteraceae & 2.00 & 2.00 & 2.30 & Yes & Herb & Annual & Nat & $\begin{array}{c}\text { Asia, } \\
\text { N America }\end{array}$ & 1 \\
\hline 20 & Bidens frondosa & Asteraceae & 3.08 & 2.48 & 3.18 & No & Herb & Annual & Nat & N America & 2 \\
\hline 21 & $\begin{array}{l}\text { Bromus } \\
\text { danthoniae }\end{array}$ & Poaceae & 2.00 & 2.00 & 2.30 & Yes & Herb & Annual & Nat & Asia, Europe & 2 \\
\hline 22 & Buddleja davidii & $\begin{array}{l}\text { Scrophu- } \\
\text { lariaceae }\end{array}$ & 0 & 1.04 & 1.04 & No & Shrub & Perennial & Nat & Asia & 2 \\
\hline 23 & $\begin{array}{l}\text { Camelina } \\
\text { microcarpa }\end{array}$ & Brassicaceae & 0 & 1.04 & 1.04 & Yes & Herb & $\begin{array}{c}\text { Annual or } \\
\text { biennial }\end{array}$ & Nat & $\begin{array}{l}\text { Africa, Asia, } \\
\text { Europe }\end{array}$ & 6 \\
\hline
\end{tabular}




\begin{tabular}{|c|c|c|c|c|c|c|c|c|c|c|c|}
\hline No & Species & Family & Env. & Soc. & $\begin{array}{l}\text { Total } \\
\text { score }\end{array}$ & $\begin{array}{l}\text { Agr. } \\
\text { weed }\end{array}$ & $\begin{array}{l}\text { Life } \\
\text { form }\end{array}$ & $\begin{array}{c}\text { Life } \\
\text { history }\end{array}$ & Status & Native range & $\begin{array}{c}\text { Number of } \\
\text { grid cells } \\
\text { (See Suppl. } \\
\text { material 1) }\end{array}$ \\
\hline 24 & Canna indica & Cannaceae & 3.04 & 0 & 3.04 & No & Herb & Perennial & Cas & S America & 5 \\
\hline 25 & $\begin{array}{l}\text { Carpobrotus } \\
\text { edulis }\end{array}$ & Aizoaceae & 4.03 & 0 & 4.03 & Yes & Herb & Perennial & Nat & S Africa & 4 \\
\hline 26 & $\begin{array}{l}\text { Conyza } \\
\text { bonariensis }\end{array}$ & Asteraceae & 2.30 & 2.30 & 2.69 & Yes & Herb & Annual & Nat & S America & 7 \\
\hline 27 & $\begin{array}{l}\text { Conyza } \\
\text { canadensis }\end{array}$ & Asteraceae & 3.08 & 3.32 & 3.52 & Yes & Herb & Annual & Nat & N America & 13 \\
\hline 28 & $\begin{array}{l}\text { Chenopodium } \\
\text { ambrosioides }\end{array}$ & $\begin{array}{l}\text { Chenopo- } \\
\text { diaceae }\end{array}$ & 1.32 & 0 & 1.32 & No & Herb & $\begin{array}{l}\text { Annual or } \\
\text { perennial }\end{array}$ & Nat & N America & 6 \\
\hline 29 & $\begin{array}{l}\text { Eichhornia } \\
\text { crassipes }\end{array}$ & $\begin{array}{l}\text { Pontede- } \\
\text { riaceae }\end{array}$ & 5.05 & 4.32 & 5.12 & No & Aquatic & Perennial & Nat & S America & 1 \\
\hline 30 & Elatine ambigua & Elatinaceae & 2.00 & 0 & 2.00 & No & Aquatic & Annual & Nat & S Asia & 3 \\
\hline 31 & Elatine triandra & Elatinaceae & 2.00 & 0 & 2.00 & No & Aquatic & Perennial & Nat & N America & 1 \\
\hline 32 & Eleusine indica & Poaceae & 2.00 & 3.04 & 3.08 & Yes & Herb & Annual & Nat & Africa & 2 \\
\hline 33 & Elodea canadensis & \begin{tabular}{|c|}
$\begin{array}{c}\text { Hydrochar- } \\
\text { itaceae }\end{array}$ \\
\end{tabular} & 4.34 & 3.30 & 4.38 & No & Aquatic & Perennial & Nat & N America & 1 \\
\hline 34 & $\begin{array}{l}\text { Eucalyptus } \\
\text { camaldulensis }\end{array}$ & Myrtaceae & 4.34 & 2.00 & 4.34 & No & Tree & Perennial & Cas & Australia & 5 \\
\hline 35 & $\begin{array}{l}\text { Ipomoea } \\
\text { purpurea }\end{array}$ & \begin{tabular}{|l} 
Convolvu- \\
laceae
\end{tabular} & 2.00 & 3.00 & 3.04 & Yes & Herb & Perennial & Nat & $\begin{array}{l}\text { C America, } \\
\text { N America }\end{array}$ & 3 \\
\hline 36 & Lantana camara & $\begin{array}{l}\text { Verban- } \\
\text { aceae }\end{array}$ & 5.05 & 4.11 & 5.10 & No & Shrub & Perennial & Cas & $\begin{array}{l}\text { C America, } \\
\text { S America }\end{array}$ & 4 \\
\hline 37 & Melia azedarach & Meliaceae & 0 & 2.32 & 2.32 & No & Tree & Perennial & Cas & Asia & 5 \\
\hline 38 & Mirabilis jalapa & $\begin{array}{l}\text { Nyctagi- } \\
\text { naceae }\end{array}$ & 2.05 & 0 & 2.05 & No & $\begin{array}{l}\text { Herb/ } \\
\text { Shrub }\end{array}$ & Perennial & Cas & $\begin{array}{l}\text { C America, } \\
\text { S America }\end{array}$ & 1 \\
\hline 39 & Nicotiana glauca & Solanaceae & 2.30 & 2.32 & 2.61 & No & Shrub & Perennial & Nat & S America & 5 \\
\hline 40 & $\begin{array}{l}\text { Panicum } \\
\text { capillare }\end{array}$ & Poaceae & 0 & 2.30 & 2.30 & No & Herb & Annual & Nat & N America & 1 \\
\hline 41 & $\begin{array}{l}\text { Phytolacca } \\
\text { americana }\end{array}$ & $\begin{array}{l}\text { Phytolac- } \\
\text { caceae }\end{array}$ & 1.04 & 1.04 & 1.32 & No & $\begin{array}{l}\text { Herb/ } \\
\text { Shrub }\end{array}$ & Perennial & Nat & N America & 7 \\
\hline 42 & $\begin{array}{l}\text { Pseudotsuga } \\
\text { menziesii }\end{array}$ & Pinaceae & 4.01 & 0 & 4.01 & No & Tree & Perennial & Cas & N America & 1 \\
\hline 43 & $\begin{array}{l}\text { Robinia } \\
\text { pseudoacacia }\end{array}$ & Fabaceae & 3.48 & 3.11 & 3.63 & No & Tree & Perennial & Nat & N America & 4 \\
\hline 44 & Sicyos angulatus & $\begin{array}{l}\text { Cucurbita- } \\
\text { ceae }\end{array}$ & 3.00 & 2.30 & 3.08 & Yes & $\begin{array}{c}\text { Herba- } \\
\text { ceous } \\
\text { Vine }\end{array}$ & Annual & Nat & N America & 2 \\
\hline 45 & $\begin{array}{l}\text { Sigesbeckia } \\
\text { pubescens }\end{array}$ & Asteraceae & 3.00 & 0 & 3.00 & No & Herb & Annual & Cas & Asia & 2 \\
\hline 46 & $\begin{array}{l}\text { Solanum } \\
\text { elaeagnifolium }\end{array}$ & Solanaceae & 3.00 & 2.00 & 3.04 & No & Herb & Perennial & Nat & S America & 1 \\
\hline 47 & $\begin{array}{l}\text { Solanum } \\
\text { pseudocapsicum }\end{array}$ & Solanaceae & 2.00 & 2.00 & 4.00 & No & Shrub & Perennial & Cas & S America & 2 \\
\hline 48 & $\begin{array}{l}\text { Solanum } \\
\text { sisymbriffolium }\end{array}$ & Solanaceae & 2.00 & 0 & 2.00 & No & Shrub & Perennial & Nat & $\begin{array}{l}\text { C America, } \\
\text { S America }\end{array}$ & 1 \\
\hline 49 & $\begin{array}{l}\text { Solidago } \\
\text { canadensis }\end{array}$ & Asteraceae & 4.00 & 2.00 & 4.01 & No & Herb & Perennial & Nat & N America & 1 \\
\hline 50 & Tagetes minuta & Asteraceae & 3.00 & 0 & 3.00 & No & Herb & Annual & Cas & S America & 7 \\
\hline 51 & $\begin{array}{l}\text { Tradescantia } \\
\text { fluminensis }\end{array}$ & $\begin{array}{c}\text { Com- } \\
\text { melinaceae }\end{array}$ & 4.34 & 2.00 & 4.34 & No & Herb & Annual & Nat & S America & 1 \\
\hline
\end{tabular}


sites to native species (1.4), impact through hybridization (1.5) and impact on ecosystems (1.6). Socioeconomic impacts are categorized as follows: impact on agricultural production (2.1), impact on animal production (2.2), impact on forestry production (2.3), impact on human infrastructure and administration (2.4), impact on human health (2.5) and impact on human social life (2.6) (see Nentwig et al. 2016). The protocols for assessing plant impacts are described in detail in Rumlerová et al. (2016).

If more than one study assessed impacts in a category and scored them differently, we assigned the species with the highest score as we were interested in potential maximum impacts (Rumlerová et al. 2016). Suppl. material 3 provides information on detailed scoring of species in each category with corresponding references. Based on the maximum scores, for each species and impact group (environmental, socioeconomic), the logarithmic sum of all values scored across the six categories was calculated $\left(\log 10\left(\Sigma\left(10^{\wedge}\right.\right.\right.$ impact values $\left.)\right)$. The logarithmic sum was used to reflect the exponential nature of the gradual increase in the levels of the GISS system, when individual levels of impact are of different orders of magnitude (see Rumlerová et al. 2016).

\section{Species traits}

For each species included in this study we recorded information on its life history (annual or perennial; Table 1) and whether the species was considered an agricultural weed in Turkey; this information was taken from literature. The region of origin was categorized as follows: Asia, America (North America, South America and Central America), Africa, Australia and Europe. The data on species traits were taken from the databases (USDA, www.plants.usda.gov; DAISIE, www.europe-aliens.org; Council of Higher Education National Centre, https://tez.yok.gov.tr/UlusalTezMerkezi/giris.jsp), theses (e.g. Yazlık 2001, Yıldırım 2001) and published papers (e.g. Yıldırım and Ekim 2003, Brundu et al. 2011). Plant names have been verified using IPNI (International Plant Name Index, http://www.ipni.org).

\section{Species distribution}

The distribution of the studied species in Turkey was expressed using a grid system (Fig. 1, Suppl. material 1) following the Flora of Turkey (Davis 1965-1985, Davis et al. 1988) and East Aegean Islands (Güner et al. 2000). The distance between the two latitudinal degrees is $220 \mathrm{~km}$ and that between the two longitudinal degrees $175 \mathrm{~km}$, with the area of a grid cell being $38,500 \mathrm{~km}^{2}$ (Akaydın and Erik 1996). The biogeographical distribution (Fig. 1) was used to assess regional differences in the types of impacts. The geographical system divides Turkey into seven regions (Marmara; Black Sea; Aegean; Mediterranean; Central Anatolia; South East Anatolia; and East Anatolia; Tuncel 2011). Data on the distribution of the species studied was taken from the following sources: Babaç (2004), Bakış et al. (2011), Eminağaoğlu et al. 


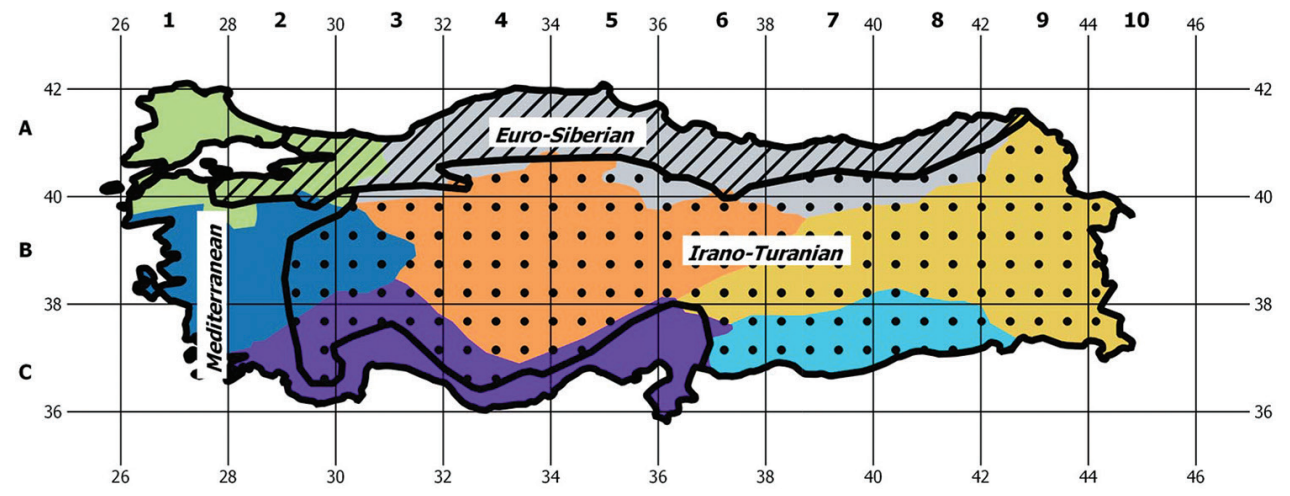

Figure I. The sections of Turkey in different systems. (i) Biogeographical system: Euro-Siberian - hatching, Mediterranean - no hatching and Irano-Turanian - dots; (ii) geographical system: $₫$ Marmara region,

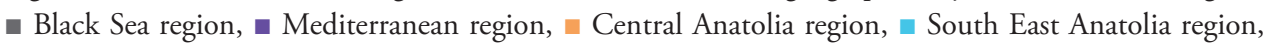
East Anatolia region, = Aegean region and (iii) the grid system according to Davis $(1965-1985,1988)$ is overlaid over the map.

(2012), Karaer and Terzioğlu (2013), Uruşak et al. (2013) and Uremis et al. (2014). Data on the extent of agricultural area was taken from the Turkish Statistical Institute (http://www.tuik.gov.tr).

\section{Statistical analyses}

The relationships between the impacts, the species and their distribution were analysed by using exploratory analyses. We compared the relationships between the scores for environmental and economic impacts with the distribution of species in Turkey (explanatory variable) by linear regression, to find out whether widely distributed species have a higher or lower than average impact in some categories. We also tested the correlation between environmental and socioeconomic impacts of individual species. The relationship between the extent of agricultural area in the region and the mean impact on agriculture of species occurring in that region was also tested by correlation. The correlations were tested by standard Pearson correlation tests (Crawley 2007). In addition, the t-test was used to analyse whether the a priori, literature-based assignment of a species as an agricultural weed was associated with its impact on agriculture and its total socioeconomic impact, as scored in our study. The analyses were done in R (Crawley 2007, R Development Core Team 2013).

\section{Results}

A total of 125 publications and 15 databases/factsheets from ISSG, USDA, CABI and NOBANIS (Suppl. material 2) were used to assign 439 individual GISS scores to the 
Table 2. The origin of the assessed species. Note that the total sum of species by regions of origin exceeds the 51 species analysed, because some of them have their origin in more than one region.

\begin{tabular}{l|c}
\hline \multicolumn{1}{c|}{ Origin } & No \\
\hline Asia & 17 \\
\hline Africa & 3 \\
\hline Americas: & 32 \\
\hline North America & 16 \\
\hline South America & 10 \\
\hline Central \& North America & 3 \\
\hline Central \& South America & 3 \\
\hline Australia & 1 \\
\hline Europe & 7 \\
\hline Species analysed & $\mathbf{5 1}$
\end{tabular}

species assessed (see Suppl. material 3). The 51 species studied belong to 41 genera and 26 families. In terms of life history, the data set included 26 perennial, 23 annuals and two species classified in both groups. There were 32 herbs, seven shrubs, three herb/ shrub, six trees, four aquatic plants and one vine. Twenty-one species are considered as agricultural weeds in literature (Table 1). Considering the origin, most of the species originate from the Americas (32) and Asia (17) (Table 2).

The five most widely distributed species occur in at least $35 \%$ of grid cells (Table 1 , Suppl. material 1): Alyssum sibiricum, Alyssum strigosum subsp. strigosum (in 14 out of 29), Alyssum dasycarpum, Conyza canadensis (13) and Alhagi pseudalhagi (11). In terms of geographical regions, the Black Sea region harbours 34 species, Marmara 28, Mediterranean region 21, Aegean region 17 and East Anatolia, Central Anatolia and South East Anatolia harbour 12 species each (Fig. 2). Species, for which we recorded impact on forestry, are present in Black Sea, Marmara and Mediterranean regions. There was a significant negative relationship between the environmental impact and the number of grid cells the species occupies in Turkey (env. impact $=-0.14 \times$ grid no.; $F_{1,50}=7.1$; $\mathrm{p}=0.01)$ and non-significant relationship for socioeconomic impact $\left(\mathrm{F}_{1,50}=0.00 ; \mathrm{p}=\right.$ 0.96) (Figs 3A, B).

There is evidence that 41 of the 51 alien plants considered in this study have environmental impacts. The impacts on ecosystem (category 1.6) and on plants or vegetation (1.1) were the most frequent amongst environmental impacts, recorded for 24 species (59\% of those with environmental impacts). Impact on other species through competition (1.3) was recorded in 18 species (43\%). Socioeconomic impacts were recorded for 40 species. The most frequent socioeconomic impact, applying to 28 species (70\% of those with socioeconomic impact), was recorded on agricultural production (2.1). The impact on human health (2.5) was recorded in 22 species (55\%) and on human social life (2.6) in eight species (20\%).

The top 22 alien species ranked according to the decreasing logarithmic sum of all impact scores across categories of environmental and socioeconomic impacts are shown in Fig. 4. Eichhornia crassipes, Lantana camara, Elodea canadensis, Eucalyptus 


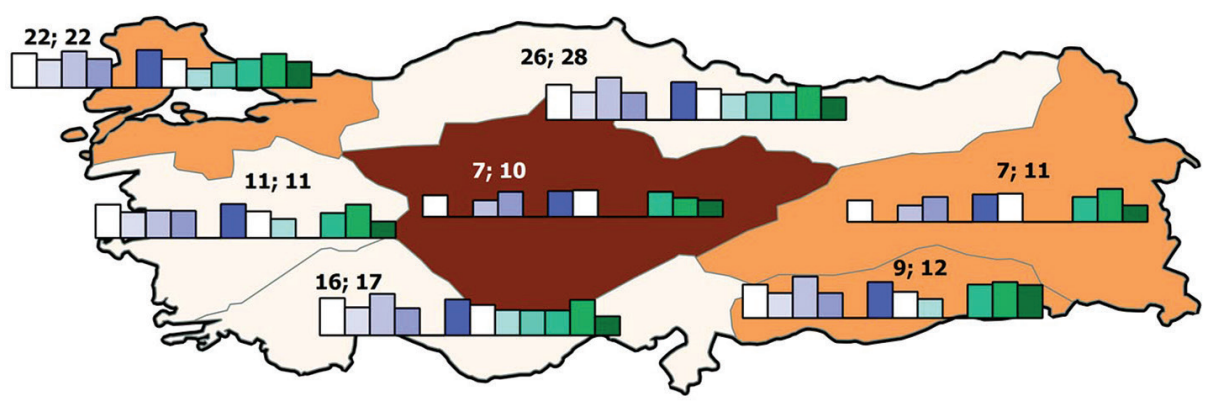

Impact categories

\begin{tabular}{|llll} 
Extent of agric. area $\mathbf{( 1 0 0 0} \mathbf{~ k m 2 )}$ & 1.1 - Plants \& vegetation & 1.5 - Hybridization & $2.3-$ Forestry \\
\hline $1900-2400$ & 1.2 - Animals & 1.6 - Ecosystem & $2.4-$ Infrastructure \\
$2400-2900$ & 1.3 - Competition & 2.1 - Agriculture & $2.5-$ Human health \\
$6500-7000$ & 1.4 - Disease transmission & 2.2 - Animal production $\square$ & $2.6-$ Social life \\
\hline$\square$
\end{tabular}

mean impact $-3 \square$ mean impact - 5

Figure 2. Map of impact types per individual geographical region. Shading of the regions reflects the extent of agricultural area (thousands of $\mathrm{km}^{2}$ in that region; TUIK 2015). The heights of the bars in the main figure are proportional to the assessed impact of alien species in the regions; two bars with mean impacts of 3 and 5 are shown as a reference. Numbers above the bars show the number of species with environmental and socioeconomic impact in the region.
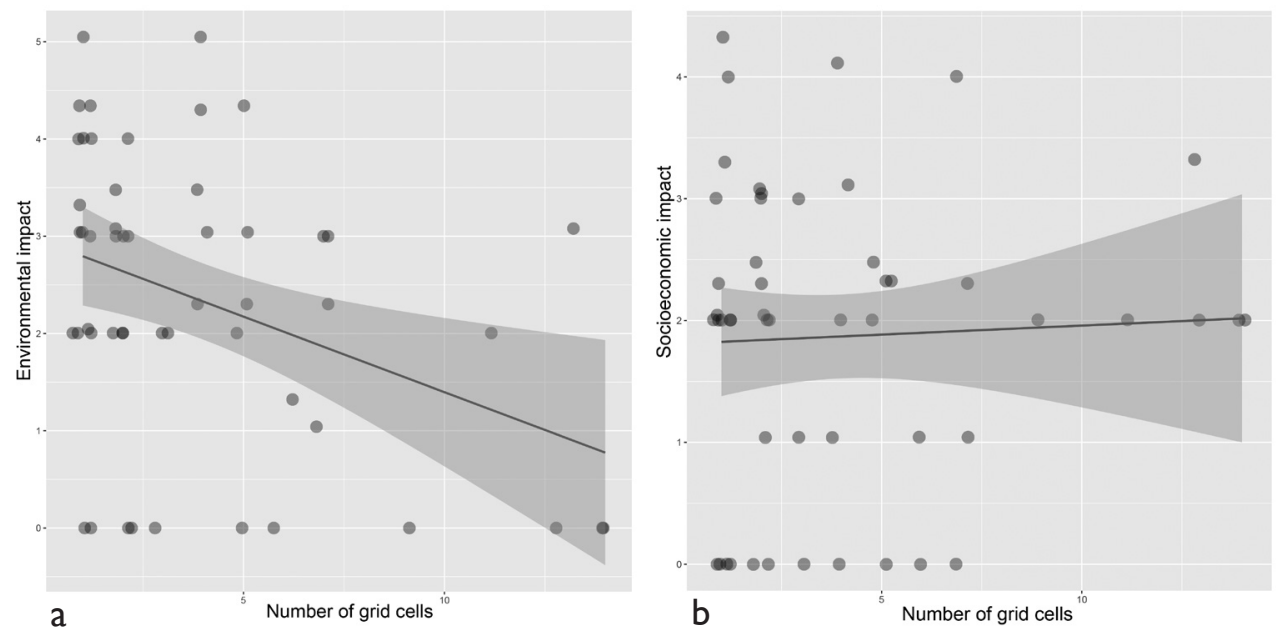

Figure 3. Correlation between the $\mathbf{a}$ environmental and $\mathbf{b}$ socioeconomic (logarithmic score) impact and distribution of alien species in Turkey (no. of occupied grid cells). Each dot represents a species.

camaldulensis, Tradescantia fluminensis, Carpobrotus edulis, Ambrosia artemisiifolia and Artemisia annua ranked the highest. The species scores of impact in socioeconomic and environmental categories were not correlated $(\mathrm{r}=0.17 ; \mathrm{df}=50 ; \mathrm{t}=1.36 ; \mathrm{p}=0.18)$. 


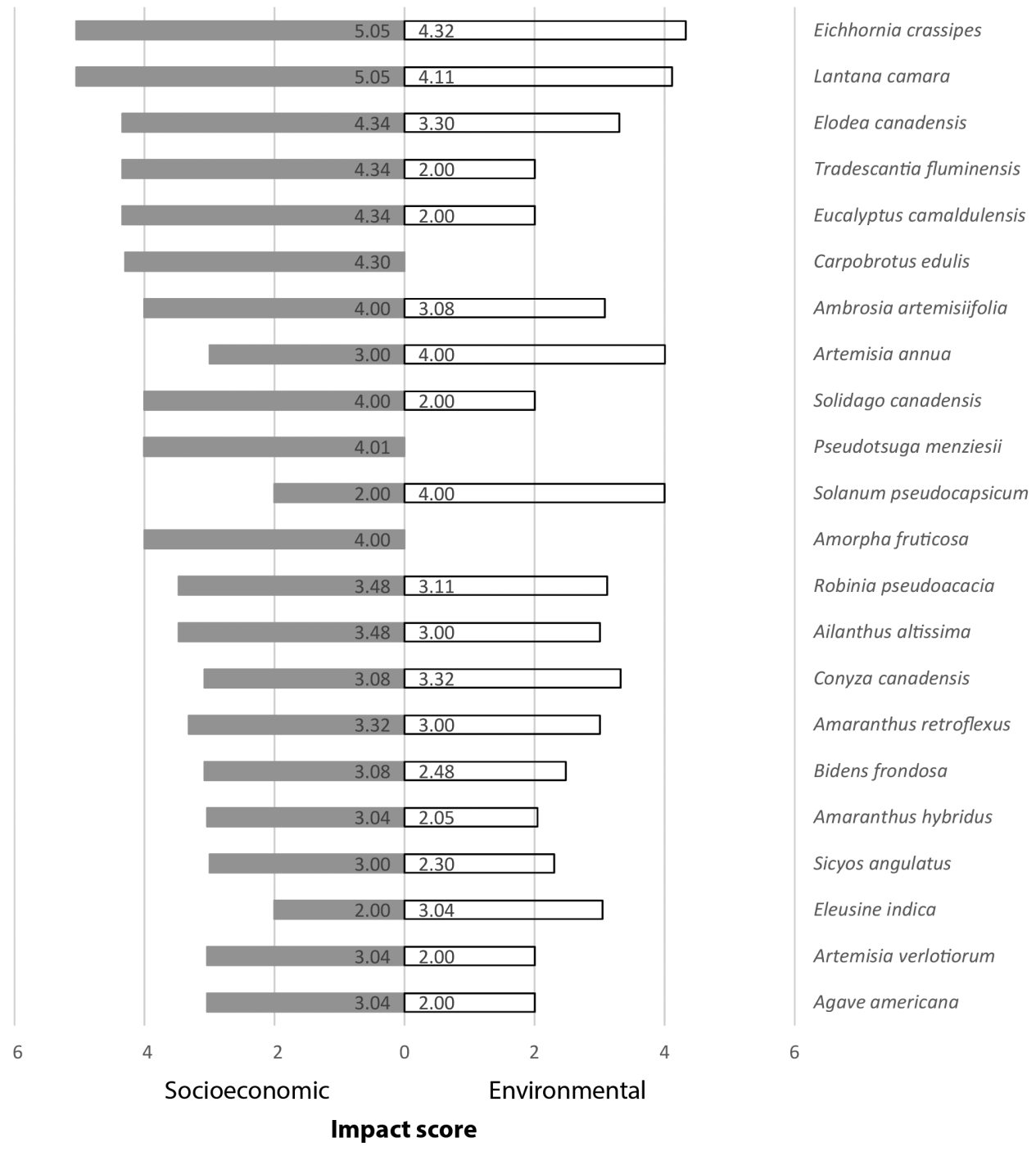

Figure 4. Top 22 alien species ranked according to decreasing logarithmic sum of all impact scores across categories of environmental (white bars) and socioeconomic (grey bars) impacts. Note that by using the logarithmic sum, the highest score recorded has the most influence on the overall score while the other scores have relatively little influence on the overall value; this approach ensures that emphasis on the maximum impact of species is maintained.

An analysis, focused on agriculture, revealed that Conyza canadensis, Amaranthus retroflexus and Ipomoea purpurea have high impacts on agricultural production (category 2.1). We found marginally significantly greater impacts on agriculture of species a priori classified as 'agricultural weeds' than of other species, not considered agricultural weeds in literature $(\mathrm{t}$-test $=2.08 ; \mathrm{df}=15 ; \mathrm{p}=0.06)$ and no significant difference between these two 
Table 3. Overview of categories scored in the two impact groups (environmental and socioeconomic), numbers of alien species for which the data were found, and \% of the 51 species screened. The numbers of scored species in categories include also zero scores.

\begin{tabular}{l|c|c|c|c|c|c|c|c|c|c|c|c}
\hline & \multicolumn{4}{|c|}{ Environmental (total 41 species) } & \multicolumn{4}{c}{ Socioeconomic (total 40 species) } \\
\hline Impact type & $\mathbf{1 . 1}$ & $\mathbf{1 . 2}$ & $\mathbf{1 . 3}$ & $\mathbf{1 . 4}$ & $\mathbf{1 . 5}$ & $\mathbf{1 . 6}$ & $\mathbf{2 . 1}$ & $\mathbf{2 . 2}$ & $\mathbf{2 . 3}$ & $\mathbf{2 . 4}$ & $\mathbf{2 . 5}$ & $\mathbf{2 . 6}$ \\
\hline Total plant & 24 & 11 & 18 & 6 & 0 & 24 & 29 & 6 & 4 & 5 & 22 & 8 \\
\hline$\%$ & 59 & 27 & 44 & 15 & 0 & 59 & 71 & 15 & 10 & 12 & 54 & 20 \\
\hline
\end{tabular}

groups in overall socioeconomic impact (t-test $=1.38 ; \mathrm{df}=55 ; \mathrm{p}=0.17)$. Of the 21 'agricultural weeds', the evidence for impact on agriculture was found for 20 , with an average score of 2.1, while, for the 30 non-weedy species, nine had a record of impact, with an average 1.8. No significant relationship between the extent of agricultural area with mean impact on agriculture (2.1) was found $(\mathrm{r}=-0.41, \mathrm{df}=5, \mathrm{t}=0.993, \mathrm{p}=0.37)$.

\section{Discussion}

The vast majority of species assessed in this study can potentially have some impact in Turkey; of the 51 species scored, we found evidence in literature of environmental and socioeconomic impacts for 41 and 40 species, corresponding to $80 \%$ and $78 \%$, respectively. For 30 assessed species, we found evidence of both environmental and socioeconomic impacts, while 11 species have only environmental and 10 species only socioeconomic impacts. Since our evidence database was compiled from primary sources in which the impacts were tested by original authors, we minimized the potential bias that might occur due to incorrect interpretation or reporting in secondary references. Another potential bias is associated with uncertainty in recording the impacts in the primary studies. We tried to minimize this by using multiple assessments of the same impact type for the same species where such data were available and taking the maximum value as in previous studies employing GISS (Kumschick et al. 2015a, Rumlerová et al. 2016).

The impacts of alien species have been traditionally evaluated to address the economic costs of invasion (Perrings et al. 2010) or to quantify direct eradication costs (Reinhardt et al. 2003); a system for a broader evaluation of a wide range of socioeconomic aspects of invasion has been developed only recently (Bacher et al. 2018). Not so long ago, environmental assessments were rather rare and those that were available used mostly economic currencies (see Jeschke et al. 2014 for overview of definitions related to impact); this has changed recently when new methods for evaluation of environmental impacts were developed (Nentwig et al. 2010, Blackburn et al. 2014, Kumschick et al. 2015b).

In our study, we considered both environmental and socioeconomic impacts of alien species that may become problematic in the near future. The highest economic impacts are likely to occur in agriculture and human health sectors. In total, 22 species (out of the 51 we assessed) occurring in agricultural areas are considered as prob- 
lematic (Yazlık 2001, Yıldırım 2001, Kitiş 2002). Some plants with strong impacts on agriculture such as Conyza canadensis and Amaranthus retroflexus occur in high abundances in different biogeographic regions and colonize a range of different habitats. This corresponds to previous reports about these species as agricultural weeds in different biogeographic regions of Turkey; in the Irano-Turanian region, Amaranthus retroflexus was recorded in 19\% and 15\% of pear and apple orchards sampled, respectively (Yazlık 2001). In the Mediterranean region, 91\% tomato fields were infested by this species and $A$. retroflexus occurred with an average density of 6.5 plants $/ \mathrm{m}^{2}$ (Kitiş 2002). The large impact of Conyza spp. (including C. canadensis; N. Doğan, personal communication) determined in this study is corroborated by evidence from the Mediterranean and Aegean regions, where herbicide-resistant biotypes have been identified (Doğan et al. 2016).

Turkey consists of three different biogeographic zones, which represent natural barriers in the naturalization-invasion process for some species, because of climatic characteristics, such as extreme temperature, or precipitation in the dry season; only five aliens with impacts assessed here are widespread across the country. Our data suggest that the cumulative impacts of many alien species only occur in some regions because the species with highest impact are not yet widely distributed over the whole country. This finding can be important for management, because the eradication of localized populations is more feasible and less costly compared to populations of widespread invaders (Pluess et al. 2012). In addition, the non-significant relationship between economic impact and distribution indicates that the overall impact of alien species in a region is proportional to their distribution and can be predicted on the basis of assumed future spread of weedy species.

For environmental impact, the highest scores were found for a diverse group of species containing Eichhornia crassipes, Lantana camara, Tradescantia fluminensis, Elodea canadensis, Eucalyptus camaldulensis, Carpobrotus edulis, Pseudotsuga menziesii and Ambrosia artemisiifolia as prominent examples. They are representatives of various life forms of plants from aquatics to shrubs and trees. This corresponds to previous findings from other regions that the impact is positively associated with height and depends on the environment, with aquatic plants having the greatest impacts (Rumlerová et al. 2016). The most common mechanism for environmental impact in our study was via ecosystem changes with direct negative effects on plants and vegetation. Compared to Rumlerová et al. (2016), competition was not the most frequent mechanism for impact in our study. Nevertheless, the above-mentioned ecosystem changes can be a consequence of indirect effects on other organizational levels that result in complex changes due to invasion.

Eichornia crassipes, Lantana camara, Artemisia annua, Solanum pseudocapsicum, Conyza canadensis, Elodea canadensis and Robinia pseudoacacia are also species with the greatest socioeconomic impacts, reaching values comparable to those of major agricultural weeds discussed above. We found only a marginally significant relationship between the species' weed status and their impacts on agriculture as scored in our study. This indicates that, in previous assessments, these species were assigned their weed 
status rather subjectively and probably on the basis of their high abundance, which does not necessarily translate into high impact.

Vilà et al. (2010) found a relatively weak correlation between the economic and ecological impacts for terrestrial plants. Our analysis provided similar results, with no relationship between the two types of impacts. This can be explained by the fact that invasive terrestrial plants are preferentially studied for selected types of impacts and the priorities about what impact to target can largely differ amongst individual assessors (Vilà et al. 2011, Hulme et al. 2013). The fact that environmental and socioeconomic impacts of plants are, to some extent, independent from each other, as indicated by the lack of correlation, calls for measuring and recording both types of impact.

For some species, potential impacts recorded here are greater than reported in a study that assessed the impacts of plant invaders in Europe using the same methods (Rumlerová et al. 2016). Theoretically, impact values should be the same across the two studies because the data should reflect the maximum impact of the species in its entire alien range. Some of these differences can be attributed to the fact that the current study used literature that was published after the scoring for the paper of Rumlerová et al. (2016) was performed and the fact that we also used local reports (e.g. Yazlık 2001, Yıldırım 2001, Kitiş 2002) to make our study as relevant for Turkey as possible. Despite some differences in the scores of some species, in general, species with the highest impacts from both studies have similar scores. For instance, the top ranked species in Turkey and Europe were the same (Lantana camara, Eichhornia crassipes, Elodea canadensis, Robinia pseudoacacia, Eucalyptus camaldulensis, Tradescantia fluminensis, Solidago canadensis and Carpobrotus edulis) and exhibited the greatest impacts in the same categories. In addition, some recently recorded species in Turkey (e.g. Tradescantia fluminensis; Eminağaoğlu et al. 2012) were classified in our study, similar to the scoring performed by Rumlerová et al. (2016), as having high impacts. This, together with the negative relationship that we found between the environmental impact of a species and its distribution, a relationship that is hard to interpret, points to the importance of scoring the impacts before the species becomes widely distributed.

A precautionary approach to invasive plants should be adopted not only in protected areas (Foxcroft et al. 2017) but also in agricultural and urban areas where alien plants with environmental and socioeconomic impacts are concentrated (Hoffmann and Broadhurst 2016, Schiffleithner and Essl 2016). The public and policy-makers more often perceive species as having negative impacts if socioeconomic sectors are affected. However, although the environmental and socioeconomic impacts were not correlated in our study, it is obvious that many species with impacts on economic sectors such as agriculture or forestry also negatively affect biodiversity and environment, for example Alhagi pseudalhagi. The same applies to competitive agricultural weeds, for example Amaranthus retroflexus (Costea et al. 2004, Vilà and Gimeno 2006), the management of which is often constrained by their increased herbicide resistance. Such assessment is needed to underpin the pathway management (Wilson et al. 2016, Pergl et al. 2017, Saul et al. 2017).

Our study is the first systematic assessment of the impacts caused by alien plants in Turkey and represents complementary information to the recently compiled in- 
ventory of alien plants in this country (Uludağ et al. 2017). The data presented here should be included into the decision process to prioritize alien species to be targeted by management and have potential to provide local authorities with a knowledge-base for addressing the regional risks for individual socioeconomic sectors and biodiversity.

\section{Acknowledgments}

This study was funded COST Action TD1209 (ALIEN CHALLENGE European Information System for Alien Species (2013-2017) Short Term Scientific Mission (STSM) "Impact assessment of selected alien plants in Turkey" COST - STSM 2015 - 300615-062105). AY thank the Department of Invasion Ecology, Institute of Botany ASCR for space and the opportunity to use their facilities. JP and PP were supported by long-term research development project RVO 67985939 from The Czech Academy of Sciences, project 17-19025S from the Grant agency of the Czech Republic and Premium Academiae award to PP from The Czech Academy of Sciences. We thank Zuzana Sixtová for the technical assistance and J. Catford and three anonymous referees for their valuable comments.

\section{References}

Akaydın G, Erik S (1996) A4 Karesi (Ankara) için yeni floristik kayıtlar. Hacettepe Üniversitesi Eğitim Fakültesi Dergisi 12: 211-213.

Babaç MT (2004) Possibility of an information system on plants of South-West Asia with particular reference to the Turkish Plants Data Service (TÜBIVES). Turkish Journal of Botany 28: 119-127.

Bacher S, Blackburn TM, Essl F, Jeschke JM, Genovesi P, Heikkilä J, Jones G, Keller R, Kenis M, Kueffer C, Martinou AF, Nentwig W, Pergl J, Pyšek P, Rabitsch W, Richardson DM, Roy HE, Saul W-C, Scalera R, Vilà M, Wilson JRU, Kumschick S (2018) Socio-economic impact classification of alien taxa (SEICAT). Methods in Ecology and Evolution 9: 159-168. https://doi.org/10.1111/2041-210X.12844

Bakış Y, Babac MT, Uslu E (2011) Updates and improvements of Turkish Plants Data Service (TüBIVES). $6^{\text {th }}$ International Symposium on Health Informatics and Bioinformatics HIBIT 2011, 136-140. https://doi.org/10.1109/HIBIT.2011.6450823

Blackburn TM, Essl F, Evans T, Hulme PE, Jeschke JM, Kühn I, Kumschick S, Marková Z, Mrugała A, Nentwig W, Pergl J, Pyšek P, Rabitsch W, Ricciardi A, Richardson DM, Sendek A, Vilà M, Wilson JRU, Winter M, Genovesi P, Bacher S (2014) A unified classification of alien species based on the magnitude of their environmental impacts. PLoS Biology 12: e1001850. https://doi.org/10.1371/journal.pbio.1001850

Blackburn TM, Pyšek P, Bacher S, Carlton JT, Duncan RP, Jarošík V, Wilson JRU, Richardson DM (2011) A proposed unified framework for biological invasions. Trends in Ecology \& Evolution 26: 333-339. https://doi.org/10.1016/j.tree.2011.03.023 
Brundu G, Aksoy N, Brunel S, Eliáš P, Fried G (2011) Rapid surveys for inventorying alien plants in the Black Sea region of Turkey. Bulletin OEPP/EPPO Bulletin 41: 208-216. https://doi.org/10.1111/j.1365-2338.2011.02455.x

Çinar ME, Bilecenoglu M, Öztürk B, Katağan T, Yokeş MB, Aysel V, Dağlı E, Açık S, Özcan T, Erdoğan H (2011) An updated review of alien species on the coasts of Turkey. Mediterranean Marine Science 12: 257-315. https://doi.org/10.12681/mms.34

Coşkunçelebi K, Terzioğlu S, Vladimirov V (2007) A new alien species for the flora of Turkey: Bidens frondosa L. (Asteraceae). Turkish Journal of Botany 31: 477-479.

Costea M, Weaver SE, Tardif FJ (2004) The biology of Canadian weeds. 130. Amaranthus retroflexus L., A. powellii S. Watson and A. hybridus L. (update). Canadian Journal of Plant Science 84: 631-668. https://doi.org/10.4141/P02-183

CrawleyMJ(2007)TheRbook. Wiley,Chichester,951pp.https://doi.org/10.1002/9780470515075

Davis PH (Ed.) (1965-1985) Flora of Turkey and the Aegean Islands, Vols 1-9. Edinburgh University Press, Edinburg.

Davis PH, Miller R, Tan K (1988) Flora of Turkey and the East Aegean Islands, Vol. 10, Supplement. Edinburgh University Press, Edinburgh.

Doğan MN, Altop-Kaya E, Türkseven S, Serim AT (2016) Akdeniz ve Ege bölgesi turunçgil ve bağ alanlarında sorun olan şifa otu türlerinin (Conyza spp.) Glyphosate'e dayanıklılığının tespiti [Determination of Glyphosate resistance of horseweed species (Conyza spp.) occurring in citrus and vineyards from Mediterranean and Aegean Regions]. In: Turkey $6^{\text {th }}$ Plant Protection Congress with International Participation September 5-8, 2016 (Konya, Turkey), 837 pp.

Ehrenfeld JG (2010) Ecosystem consequences of biological invasions. Annual Review of Ecology, Evolution, and Systematics 41: 59-80. https://doi.org/10.1146/annurev-ecolsys-102209-144650

Eminağaoğlu Ö, Özcan M, Kültür Ş (2012) Contributions to the leaf and stem anatomy of Tradescantia fluminensis an alien species new to the flora of Turkey. Artvin Çoruh Üniversitesi Orman Fakültesi Dergisi 13: 270-277.

EU (2014) Regulation (EU) No 1143/2014 of the European Parliament and of the Council of 22 October 2014 on the prevention and management of the introduction and spread of invasive alien species. Official Journal of the European Union, Brussels.

Foxcroft LC, Pyšek P, Richardson DM, Genovesi P, MacFadyen S (2017) Plant invasion science in protected areas: Progress and priorities. Biological Invasions 19: 1353-1378. https://doi.org/10.1007/s10530-016-1367-z

Genovesi P, Carboneras C, Vilà M, Walton P (2015) EU adopts innovative legislation on invasive species: A step towards a global response to biological invasions? Biological Invasions 17: 1307-1311. https://doi.org/10.1007/s10530-014-0817-8

Güner A, Aslan S, Ekim T, Vural M, Babaç MT (2012) Türkiye Bitkileri Listesi (Damarlı Bitkiler) [Turkey plants list (Vascular plants)]. Nezahat Gökyiğit Botanical Garden and Flora Research Association Publication, Istanbul.

Güner A, Özhatay N, Ekim T, Baser KHC (Eds) (2000) Flora of Turkey and the Aegean Islands, Vol. 11, Supplement 2. Edinburg University Press, Edinburgh.

Hawkins CL, Bacher S, Essl F, Hulme PE, Jeschke JM, Kühn I, Kumschick S, Nentwig W, Pergl J, Pyšek P, Rabitsch W, Richardson DM, Vilà M, Wilson JRU, Genovesi P, Blackburn TM (2015) Framework and guidelines for implementing the proposed IUCN Envi- 
ronmental Impact Classification for Alien Taxa (EICAT). Diversity and Distributions 21: 1360-1363. https://doi.org/10.1111/ddi.12379

Hoffmann BD, Broadhurst LM (2016) The economic cost of managing invasive species in Australia. NeoBiota 31: 1-18. https://doi.org/10.3897/neobiota.31.6960

Hulme PE, Pyšek P, Jarošík V, Pergl J, Schaffner U, Vilà M (2013) Bias and error in current knowledge of plant invasions impacts. Trends in Ecology \& Evolution 28: 212-218. https://doi.org/10.1016/j.tree.2012.10.010

Jeschke JM, Bacher S, Blackburn TM, Dick JTA, Essl F, Evans T, Gaertner M, Hulme PE, Kühn I, Mrugała A, Pergl J, Pyšek P, Rabitsch W, Ricciardi A, Richardson DM, Sendek A, Vilà M, Winter M, Kumschick S (2014) Defining the impact of non-native species. Conservation Biology 28: 1188-1194. https://doi.org/10.1111/cobi.12299

Karaer F, Kutbay HG (2007) Solanum sisymbriffolium Lam. (Solanaceae): A new record for Turkey. Turkish Journal of Botany 31: 481-483.

Karaer F, Terzioğlu S (2013) A new alien record for the flora of Turkey: Sigesbeckia pubescens (Compositae). Turkish Journal of Botany 37: 188-190. https://doi.org/10.3906/bot-1202-45

Kitiş YE (2002) Isparta ili domates ekiliş alanlarındaki yabancı otların, rastlama sıklıklarının ve yoğunluklarının belirlenmesi ve plastik toprak örtülerinin yabancı ot kontrolü ve domates verimine etkileri [Determination of the weed species, their observation frequencies and densities in tomato fields in Isparta province and effects of plastic soil covers on weed control and tomato yield]. Master thesis. Süleyman Demirel Üniversitesi Fen Bilimleri Enstitüsü Yüksek Lisans Tezi, Isparta.

Kumschick S, Bacher S, Evans T, Marková Z, Pergl J, Pyšek P, Vaes-Petignat S, van der Veer G, Vilà M, Nentwig W (2015a) Comparing impacts of alien plants and animals in Europe using a standard scoring system. Journal of Applied Ecology 52: 552-561. https://doi.org/10.1111/13652664.12427

Kumschick S, Gaertner M, Vilà M, Essl F, Jeschke JM, Pyšek P, Ricciardi A, Bacher S, Blackburn TM, Dick JTA, Evans T, Hulme PE, Kühn I, Mrugała A, Pergl J, Rabitsch W, Richardson DM, Sendek A, Winter M (2015b) Ecological impacts of alien species: Quantification, scope, caveats and recommendations. BioScience 65: 55-63. https://doi.org/10.1093/biosci/biu193

Kumschick S, Nentwig W (2010) Some alien birds have as severe an impact as the most effectual alien mammals in Europe. Biological Conservation 143: 2757-2762. https://doi.org/10.1016/j. biocon.2010.07.023

Kumschick S, Vimercati G, de Villiers FA, Mokhatla MM, Davies SJ, Thorp CJ, Rebelo AD, Measey GJ (2017) Impact assessment with different scoring tools: How well do alien amphibian assessments match? NeoBiota 33: 53-66. https://doi.org/10.3897/neobiota.33.10376

Lambdon PW, Pyšek P, Basnou C, Hejda M, Arianoutsou M, Essl F, Jarošík V, Pergl J, Winter M, Anastasiu P, Andriopoulos P, Bazos I, Brundu G, Celesti-Grapow L, Chassot P, Delipetrou P, Josefsson M, Kark S, Klotz S, Kokkoris Y, Kühn I, Marchante H, Perglová I, Pino J, Vilà M, Zikos A, Roy D, Hulme PE (2008) Alien flora of Europe: Species diversity, temporal trends, geographical patterns and research needs. Preslia 80: 101-149.

Laverty C, Nentwig W, Dick JTA, Lucy FE (2015) Alien aquatics in Europe: Assessing the relative environmental and socio-economic impacts of invasive aquatic macroinvertebrates and other taxa. Management of Biological Invasions 6: 341-350. https://doi.org/10.3391/mbi.2015.6.4.03 
Nentwig W, Bacher S, Kumschick S, Pyšek P, Vilà M (2018) More than "100 worst” alien species in Europe. Biological Invasions 20: 1611-1621. https://doi.org/10.1007/s10530-017-1651-6

Nentwig W, Bacher S, Pyšek P, Vilà M, Kumschick S (2016) The Generic Impact Scoring System (GISS): A standardized tool to quantify the impacts of alien species. Environmental Monitoring and Assessment 188: 315. https://doi.org/10.1007/s10661-016-5321-4

Nentwig W, Kuhnel E, Bacher S (2010) A generic impact-scoring system applied to alien mammals in Europe. Conservation Biology 24: 302-311. https://doi.org/10.1111/j.15231739.2009.01289.x

Novoa A, Kumschick S, Richardson DM, Rouget M, Wilson JRU (2016) Native range size and growth form in Cactaceae predict invasiveness and impact. NeoBiota 30: 75-90. https://doi.org/10.3897/neobiota.30.7253

Parker IM, Simberloff D, Lonsdale WM, Goodell K, Wonham M, Kareiva PM, Williamson MH, Von Holle B, Moyle PB, Byers JE, Goldwasser L (1999) Impact: Toward a framework for understanding the ecological effects of invaders. Biological Invasions 1: 3-19. https://doi.org/10.1023/A:1010034312781

Pergl J, Pyšek P, Bacher S, Essl F, Genovesi P, Harrower CA, Hulme PE, Jeschke JM, Kenis M, Kühn I, Perglová I, Rabitsch W, Roques A, Roy DB, Roy HE, Vilà M, Winter M, Nentwig W (2017) Troubling travellers: Are ecologically harmful alien species associated with particular introduction pathways? NeoBiota 32: 1-20. https://doi.org/10.3897/neobiota.32.10199

Pergl J, Sádlo J, Petrusek A, Laštůvka Z, Musil J, Perglová I, Šanda R, Šefrová H, Šíma J, Vohralík V, Pyšek P (2016) Black, Grey and Watch Lists of alien species in the Czech Republic based on environmental impacts and management strategy. NeoBiota 28: 1-37. https://doi.org/10.3897/neobiota.28.4824

Perrings Ch, Mooney H, Williamson M (2010) Bioinvasions and globalization. Ecology, economics, management, and policy. Oxford University Press, New York, 288 pp.

Pluess T, Jarošík V, Pyšek P, Cannon R, Pergl J, Breukers A, Bacher S (2012) Which factors affect the success or failure of eradication campaigns against alien species? PlosOne 7: e48157. https://doi.org/10.1371/journal.pone.0048157

Pyšek P, Jarošík V, Hulme PE, Pergl J, Hejda M, Schaffner U, Vilà M (2012) A global assessment of invasive plant impacts on resident species, communities and ecosystems: The interaction of impact measures, invading species' traits and environment. Global Change Biology 18: 1725-1737. https://doi.org/10.1111/j.1365-2486.2011.02636.x

Pyšek P, Richardson DM (2010) Invasive species, environmental change and management, and health. Annual Review of Environment and Resources 35: 25-55. https://doi.org/10.1146/ annurev-environ-033009-095548

Pyšek P, Richardson DM, Rejmánek M, Webster GL, Williamson M, Kirschner J (2004) Alien plants in checklists and floras: Towards better communication between taxonomists and ecologists. Taxon 53: 131-143. https://doi.org/10.2307/4135498

R Development Core Team (2013) R: A language and environment for statistical computing. Vienna, Austria: the R Foundation for Statistical Computing. http:/www.R-project.org/.

Reinhardt F, Herle M, Bastiansen F, Streit B (2003) Economic impact of the spread of alien species in Germany. Report No. UBA-FB. Biological and Computer Sciences Division; Dept. of Ecology and Evolution, Frankfurt am Main, 193 pp. 
Ricciardi A, Hoopes MF, Marchetti MP, Lockwood JL (2013) Progress toward understanding the ecological impacts of nonnative species. Ecological Monographs 83: 263-282. https://doi.org/10.1890/13-0183.1

Richardson DM, Pyšek P (2006) Plant invasions: Merging the concepts of species invasiveness and community invasibility. Progress in Physical Geography 30: 409-431. https://doi. org/10.1191/0309133306pp490pr

Richardson DM, Pyšek P, Rejmánek M, Barbour MG, Panetta FD, West CJ (2000) Naturalization and invasion of alien plants: Concepts and definitions. Diversity and Distributions 6: 93-107. https://doi.org/10.1046/j.1472-4642.2000.00083.x

Roy H, Schonrogge K, Dean H, Peyton J, Branquart E, Vanderhoeven S, Copp G, Stebbing P, Kenis M, Rabitsch W, Essl F, Schindler S, Brunel S, Kettunen M, Mazza L, Nieto A, Kemp J, Genovesi P, Scalera R, Stewart A (2013) Invasive alien species - framework for the identification of invasive alien species of EU concern (ENV.B.2/ETU/2013/0026). Project final report, European Commission, Brussels, 298 pp.

Rumlerová Z, Vilà M, Pergl J, Nentwig W, Pyšek P (2016) Scoring environmental and socioeconomic impacts of alien plants invasive in Europe. Biological Invasions 18: 3697-3711. https://doi.org/10.1007/s10530-016-1259-2

Saul W-C, Roy HE, Booy O, Carnevali L, Chen H-J, Genovesi P, Harrower CA, Hulme PE, Pagad S, Pergl J, Jeschke JM (2017) Assessing patterns in introduction pathways of alien species by linking major invasion data bases. Journal of Applied Ecology 54: 657-669. https://doi.org/10.1111/1365-2664.12819

Schiffleithner V, Essl F (2016) Is it worth the effort? Spread and management success of invasive alien plant species in a Central European National Park. NeoBiota 31: 43-61. https://doi. org/10.3897/neobiota.31.8071

Schindler S, Staska B, Adam M, Rabitsch W, Essl F (2015) Alien species and public health impacts in Europe: A literature review. NeoBiota 27: 1-23. https://doi.org/10.3897/neobiota.27.5007

Simberloff D, Martin J-L, Genovesi P, Maris V, Wardle DA, Aronson J, Courchamp F, Galil B, García-Berthou E, Pascal M, Pyšek P, Sousa R, Tabacchi E, Vilà M (2013) Impacts of biological invasions: what's what and the way forward. Trends in Ecology and Evolution 28: 58-66. https://doi.org/10.1016/j.tree.2012.07.013

Sladonja B, Sušek M, Guillermic J (2015) Review on invasive tree of heaven (Ailanthus altissima (Mill.) Swingle) conflicting values: Assessment of its ecosystem services and potential biological threat. Environmental Management 56: 1009-1034. https://doi.org/10.1007/ s00267-015-0546-5

Terzioğlu S, Ansin R (1999) Türkiye’nin Egzotik Bitkilerine Bir Katkı: Sicyos angulatus L. Turkish Journal of Agriculture and Forestry 23: 359-362.

TUIK (2015) Turkish Statistical Institute - TUIK. http://www.tuik.gov.tr [Access date: 22.12.2016]

Tuncel M (2011) Birinci coğrafya kongresi'nde Türkiye coğrafi bölgelerinin isimlendirilmesi, sınırlarının tespiti ve günümüze etkileri [Regions of Turkey geographical nomenclature of the first geography congress (1941) and its effects on detection limits]. Türk Coğrafya Dergisi Sayı 57: 1-10. 
Uludağ A, Aksoy N, Yazlık A, Arslan ZF, Yazmış E, Uremis I, Cossu T, Groom Q, Pergl J, Pyšek P, Brundu G (2017) Alien flora of Turkey: Checklist, taxonomic composition and ecological attributes. NeoBiota 35: 61-85. https://doi.org/10.3897/neobiota.35.12460

Uremiş I, Uludag A, Arslan ZF, Abacı O (2014) A new record for the flora of Turkey: Eichhornia crassipes (Mart.) Solms (Pontederiaceae). Bulletin OEPP/EPPO Bulletin 44: 83-86. https:// doi.org/10.1111/epp.12096

Uruşak EA, Ozhatay FN, Guler N, Ersoy H, Başak N, Yeşil Y, Oral D, Demirci S (2013) The flora of Yıldız Mountains (Kırklareli) Biosphere Project area. Turkish Journal of Botany 37: 225-269. https://doi.org/10.3906/bot-1111-5

Vaes-Petignat S, Nentwig W (2014) Environmental and economic impact of alien terrestrial arthropods in Europe. NeoBiota 22: 23-42. https://doi.org/10.3897/neobiota.22.6620

van der Veer G, Nentwig W (2014) Environmental and economic impact assessment of alien and invasive fish species in Europe using the generic impact scoring system. Ecology of Freshwater Fish 24: 646-656. https://doi.org/10.1111/eff.12181

Vilà M, Basnou C, Pyšek P, Josefsson M, Genovesi P, Gollasch S, Nentwig W, Olenin S, Roques A, Roy D, Hulme PE, DAISIE Partners (2010) How well do we understand the impacts of alien species on ecosystem services? A pan-European, cross-taxa assessment. Frontiers in Ecology and the Environment 8: 135-144. https://doi.org/10.1890/080083

Vilà M, Espinar J, Hejda M, Hulme PE, Jarošík V, Maron J, Pergl J, Schaffner U, Sun Y, Pyšek P (2011) Ecological impacts of invasive alien plants: A meta-analysis of their effects on species, communities and ecosystems. Ecology Letters 14: 702-708. https://doi.org/10.1111/ j.1461-0248.2011.01628.x

Vilà M, Gimeno I (2006) Potential for higher invasiveness of the alien Oxalis pes-caprae on islands than on the mainland. Plant Ecology 183: 47-53. https://doi.org/10.1007/s11258005-9005-3

Vítková M, Müllerová J, Sádlo J, Pergl J, Pyšek P (2017) Black locust (Robinia psendoacacia) beloved and despised: A story of an invasive tree in Central Europe. Forest Ecology and Management 384: 287-302. https://doi.org/10.1016/j.foreco.2016.10.057

Weber E (2003) Invasive plant species of the world: A reference guide to environmental weeds. CAB International Publishing, Wallingford, 596 pp.

Wilson CE, Castro KL, Thurston GB, Sissons A (2016) Pathway risk analysis of weed seeds in imported grain: A Canadian perspective. NeoBiota 30: 49-74. https://doi.org/10.3897/ neobiota.30.7502

Yazlık A (2001) Van ve yöresinde elma ve armut bahçelerinde yabancı otlar ve dağılışları [Weeds in apple and pear orchards in Van and their distributions]. Master thesis. Yüzüncü Yil Üniversitesi (YYU) Fen Bilimleri Enstitüsü, Van.

Yıldırım A (2001) Orta Anadolu Bölgesi yabancı ot florası [Weed flora of Central Anatolia]. Ph.D. Thesis. Gazi Üniversitesi Fen Bilimleri Enstitüsü, Biyoloji Anabilim Dalı (Ankara).

Yıldırım A, Ekim T (2003) Orta Anadolu Bölgesi yabancı ot florası [Weed flora of Central Anatolia]. Bitki Koruma Bülteni 43: 1-98. https://doi.org/10.16955/bkb.85881 


\section{Supplementary material I}

\section{Distribution of alien species assessed in this study}

Authors: Ayşe Yazlık, Jan Pergl, Petr Pyšek

Data type: Distribution.

Explanation note: Distribution in Turkey of the alien species studied using the grid system according to Davis (1965-1985, 1988).

Copyright notice: This dataset is made available under the Open Database License (http://opendatacommons.org/licenses/odbl/1.0/). The Open Database License $(\mathrm{ODbL})$ is a license agreement intended to allow users to freely share, modify, and use this Dataset while maintaining this same freedom for others, provided that the original source and author(s) are credited.

Link: https://doi.org/10.3897/neobiota.39.23598.suppl1

\section{Supplementary material 2}

\section{List of references}

Authors: Ayşe Yazlık, Jan Pergl, Petr Pyšek

Data type: References.

Explanation note: List of references used for scoring the impact of the studied species. Copyright notice: This dataset is made available under the Open Database License (http://opendatacommons.org/licenses/odbl/1.0/). The Open Database License $(\mathrm{ODbL})$ is a license agreement intended to allow users to freely share, modify, and use this Dataset while maintaining this same freedom for others, provided that the original source and author(s) are credited.

Link: https://doi.org/10.3897/neobiota.39.23598.suppl2

\section{Supplementary material 3}

\section{Scoring of the impact}

Authors: Ayşe Yazlık, Jan Pergl, Petr Pyšek

Data type: Impact scores.

Explanation note: Scoring of environmental and socioeconomi impact. File contains values (Impact score) and categories in which these scores are assigned (Impact type), with source references.

Copyright notice: This dataset is made available under the Open Database License (http://opendatacommons.org/licenses/odbl/1.0/). The Open Database License $(\mathrm{ODbL})$ is a license agreement intended to allow users to freely share, modify, and use this Dataset while maintaining this same freedom for others, provided that the original source and author(s) are credited.

Link: https://doi.org/10.3897/neobiota.39.23598.suppl3 